\title{
Cultural, Morphological and Molecular Variability of Fusarium oxysporum f. sp. Ciceri Isolates by RAPD Method
}

\author{
D.S. Thaware ${ }^{1}$, O.D. Kohire ${ }^{2}$ and V.M. Gholve ${ }^{3}$ \\ Department of Plant Pathology, Ratnai College of Agriculture, \\ Akluj (MPKV, Rahuri) 431101 (Maharashtra), India \\ *Corresponding author:
}

\section{Keywords}

Chickpea wilt, Fusarium oxysporum, Molecular variability, Pigmentation and RAPD.

\section{Article Info}

Accepted:

25 January 2017

Available Online:

10 April 2017

\section{A B S T R A C T}

Cultural, morphological and molecular characteristics of Fusarium oxysporum f. sp. ciceri, eight isolates indicated a great variability amongst them. However, the isolate FOC-2 (Jalna) exhibited maximum mycelial growth of $90.00 \mathrm{~mm}$. The isolates viz., Jalna (FOC-2) and Beed (FOC-3) produced partially submerged (FOC-2) to submerged (FOC-3) white sparse dense growth with smooth margin and bright white substrate pigmentation. Maximum micro-conidial, macro-conidial and chlamydospore size $(17.20 \mu \mathrm{m}, 30.50 \mathrm{x}$ $7.00 \mu \mathrm{m}$ and $21.80 \times 19.60 \mu \mathrm{m}$ ) was recorded in isolate Jalna (FOC-2). The micro-conidia were more or less oval to cylindrical with no septation. The macro-conidia were typically sickle shaped curved, fusoid varied in the size and number of septation (3-5). The chlamydospores were round to oval in shape. Genetic diversity was analyzed based on data obtained by 10 RAPD primers. Most of the primers were found 91.66 to 100 per cent polymorphic in nature. All primers had amplified total number of 144 bands among which 140 and 4 were found polymorphic and monomorphic, respectively. The cluster I comprised isolates FOC-1 (Aurangabad) and FOC-6 (Nanded) together and showed 57.60 per cent similarity to each other; however, cluster II comprised six isolates [FOC-2 (Jalna), FOC-3 (Beed), FOC-4 (Osmanabad), FOC-5 (Latur), FOC-7 (Parbhani) and FOC-8 (Hingoli)] together showing 53.88 per cent similarity. All of these six isolates of cluster II were from different region showing maximum similarity in the range of 59.00 to 100 per cent.

\section{Introduction}

Chickpea (Cicer arietinum L.) is an important pulse crop, which belongs to leguminoceae (Dhar and Gurha, 1998). The centre of origin is in Eastern Mediterranean. India is largest producer of chickpea in world sharing 65.25 per cent in area and 65.49 per cent in production. In India chickpea is grown on 10.23 million ha area with production 9.88 million tonnes and productivity $967 \mathrm{~kg} / \mathrm{ha}$. The production of chickpea in Maharashtra is 1.62 million tonnes with productivity 891 $\mathrm{kg} / \mathrm{ha}$ which covered nearly 1.82 million ha of area. Maharashtra contributes about 16.42 per cent share in total production of country (Anonymous, 2014).

The major limiting factor in chickpea production is Fusarium wilt which is caused by $F$. oxysporum Schlechtend. Fr. f. sp. ciceris (Padwick) Matuo and K. Sato. (Nene and Reddy, 1987). It was first reported in Indo-Pak sub-continent (Butler, 1918). It 
observed damage to be upto 61 per cent at seedling stage and 43 per cent at flowering stage (Nema and Khare, 1973). In general, the disease causes substantial yield losses which may reach even 100 per cent under favourable weather conditions (Jalali and Chand, 1992). The chickpea is cultivated as a rain fed crop in Maharashtra state and yield losses amounted to 10 to 15 per cent (Khillare et al., 2009).

In the RAPD assays DNA banding patterns allowed the identification of markers which differentiate among wilting and yellowing pathotypes (Kelly et al., 1994). Pathogen $F$. oxysporum f. sp. ciceris has two pathotypes and eight pathogenic races on chickpea. These were identified as, $0,1 \mathrm{~A}, 1 \mathrm{~B} / \mathrm{C}, 2,3,4,5$, and 6 , on differential chickpea genotypes. PCR based RAPD (Random Amplified Polymorphic DNA) markers require small amount of DNA (Williams et al., 1990). The RAPD techniques for genetic diversity studies on chickpea have been proved useful in evolutionary biology (Reddy et al., 2002), gene tagging (Rajesh et al., 2002) and phylogeny studies (Iruela et al., 2002).

\section{Materials and Methods}

Cultural variability: Eight isolates of Fusarium oxysporum f. sp. ciceri obtained were aseptically inoculated separately on autoclaved and cooled PDA medium in sterile glass Petri plates (90 $\mathrm{mm}$ dia.) and incubated at $28 \pm 2^{0} \mathrm{C}$ for a week. Observations on cultural characteristics (colony diameter, colony characters and pigmentation colour) and conidial production were recorded at a week and two weeks of incubation, respectively.

\section{Morphological variability: The} morphological characteristics of conidial size (chlamydospores, micro-conidia and macroconidia) in respect of each test isolate were recorded. The size of conidia was measured using ocular micrometer (calibrated using stage micrometer) under the compound microscope (make: Labomed Vision 2000) at 400X magnification.

Molecular variability: The isolates for RAPD were selected based on their morphological, cultural virulence i.e. the most virulent isolates from diverse area were selected. This was done based on the results obtained in morphological, cultural and pathogenic reaction. Isolates selected for RAPD analysis viz., Aurangabad (FOC-1), Jalna (FOC-2), Beed (FOC-3), Osmanabad (FOC-4), Latur (FOC-5), Nanded (FOC-6), Parbhani (FOC-7) and Hingoli (FOC-8). 11 RAPD primers commercially synthesized by Siga Company were used for the present study. The random amplified polymorphic DNA (RAPD) sequence analysis was used to detect the variations among the isolates of species of Fusarium oxysporum f. sp. ciceri. The standardized protocols of isolation of DNA and RAPD reaction (Kadam, 2012) were adopted for this study.

Genomic DNA extraction: The liquid culture of each isolate was raised in conical flask. PDB (Potato dextrose broth) $100 \mathrm{ml}$ was inoculated with $7 \mathrm{~mm}$ bit of culture disc cut from edge of 5 days old culture of each isolate grown in Petri dish. The inoculated broth was incubated at $28 \pm 2{ }^{\circ} \mathrm{C}$ for 7 days. The mycelial mat was filtered through Whatman no. 1 filter paper and dried at room temperature. The dry mycelium was transferred to sterile mortar and pestle and ground with glasswool. The DNA extraction buffer and a mixture of buffer saturated phenol / chloroform / isoamyl alcohol (25:24:1) was added per $0.5 \mathrm{gm}$ of starting tissue and the solution was ground thoroughly. The mixture was then transferred into several microfuge tubes and centrifuged at $16000 \mathrm{xg}$ for $5 \mathrm{~min}$ at room temperature to pellet tissue debris and the glass wool, pellet to the bottom of tube. The aqueous phase was 
transferred to a new tube. The DNA in each tube was precipitated with 0.6 volume of isopropanol by incubating the mixture at room temperature for $10 \mathrm{~min}$. The DNA was recovered by centrifugation. The pellet was rinsed with 70 per cent ethanol, air dried briefly and resuspended in $340 \mu \mathrm{TE}$ buffer containing RNase A at $20 \mu \mathrm{l} / \mathrm{ml}$. The extracted DNA was resolved on 0.8 per cent Agarose gel. The quantification was done by spectrophotometer and stored at $-20^{\circ} \mathrm{C}$ until further use. The quantity of DNA was determined by monitoring the absorbance at $260 \mathrm{~nm}$ in a biophotometer. The $\mathrm{A}_{260} / \mathrm{A}_{280}$ ratio was checked for quality of DNA.

RAPD DNA fingerprint analysis: The PCR protocol for RAPD reaction was optimized with various PCR components and thermal cycler programme. Master mixture $(24.0 \mu \mathrm{l})$ containing all the above reactants, except template DNA were dispensed in autoclaved PCR tubes $(0.2 \mathrm{ml})$. Genomic DNA of each isolates of Fusarium oxysporum f. sp. ciceri was added to the individual tubes containing the master mixture. The contents of each tube were mixed by tapping with fingers followed by a brief spin to collect contents at the bottom of the tube. The amplified RAPD product was separated on 1.2 per cent agarose gel, stained with ethidium bromide and visualized under Gel documentation system. The polymorphism was detected by comparing RAPD product of all Fusarium oxysporum f. sp. ciceri isolates.

Scoring and data Analysis: RAPD markers across the eight isolates were scored for their presence ' 1 ' or absence ' 0 ' of bands for each primer. The data were entered into binary matrix and subsequently analyzed using NTSYS-pc version 2.10. Coefficients of similarity were calculated by using Jaccard's similarity coefficient by SIMQUAL function and cluster analysis was performed by agglomerative technique using the UPGMA (Un-weighted Pair Group Method with Arithmetic Mean) method by SAHN clustering function of NTSYS-pc. Relationships between the eight isolates of Fusarium oxysporum f. sp. ciceri were graphically represented in the form of dendrograms. In this method the dendrogram and similarity matrix were correlated to find the goodness of fit of the dendrogram constructed based on the similarity coefficients. The matrix comparison was carried out using the MXCOMP function in the NTSYS-pc version $2.02 \mathrm{i}$.

\section{Polymorphism percentage}

Polymorphism percent $=$
Total number of bands
C

\section{Results and Discussion}

\section{Cultural variability}

Results (Table 1 and Plate I) revealed that all the eight representative isolates of Fusarium oxysporum f. sp. ciceri exhibited a great variability in respect of colony diameter, colony characteristics, pigmentation colour and sporulation. The radial mycelial growth of the test isolates was ranged from $87.66 \mathrm{~mm}$ (FOC-1) to $90.00 \mathrm{~mm}$ (FOC-2). However, maximum mycelial growth was recorded by Jalna (FOC-2) isolate $(90.00 \mathrm{~mm})$, followed by the isolates viz., Parbhani (FOC-7), Beed (FOC-3), Latur (FOC-5), Osmanabad (FOC4), Hingoli (FOC-8) and Nanded (FOC-6), recorded moderate mycelial growth of test 
pathogen, $89.66 \mathrm{~mm}, 88.66 \mathrm{~mm}, 88.66 \mathrm{~mm}$, $88.33 \mathrm{~mm}, 88.33 \mathrm{~mm}$ and $88.00 \mathrm{~mm}$, respectively. The isolate, Aurangabad (FOC1) recorded comparatively less mycelial growth $(87.66 \mathrm{~mm})$ of the test pathogen.

The isolates viz., Aurangabad (FOC-1) and Nanded (FOC-6) produced submerged, white sparse growth in concentric ring and thread like flagging (FOC-6) with pale white substrate pigmentation respectively, at $7^{\text {th }}$ days after incubation. The isolates viz., Jalna (FOC-2) and Beed (FOC-3) produced partially submerged (FOC-2) to submerged (FOC-3) white sparse dense growth with smooth margin and bright white substrate pigmentation, respectively; whereas, Osmanabad (FOC-4) and Latur (FOC-5) isolates produced white cottony, fluffy growth with smooth margin and creamy white substrate pigmentation. The isolates Parbhani (FOC-7) and Hingoli (FOC-8) produced white compact and fluffy growth of mycelium with purple pink (FOC-7) and bright white substrate pigmentation in culture plates.

The sporulation induced by all the test isolates was varied from fair $(+)$ to excellent $(++++)$. However, excellent sporulation $(++++)$ was induced by the isolates viz., Aurangabad (FOC-1), Jalna (FOC-2), Osmanabad (FOC4) and Nanded (FOC-6); whereas, good sporulation (+++) was recorded by the isolates viz., Beed (FOC-3) and Parbhani (FOC-7). The isolates viz., Latur (FOC-5) and Hingoli (FOC-8) were found fair in sporulation.

These results of the present study are in consonance with the previous findings of many workers (Ahmed, 2010; Islam et al., 2011; Nagare, 2011 and Ansar and Srivastva, 2013). Mahsane, (2013) studied the cultural characteristics and reported that three isolates were produced light pink, five were creamy, one were light brown, six were light yellow, three were light to dark coloured pigmentation. Colonies of six isolates were found fluffy, six were suppressed and six were partially suppressed. Awachar, (2014) studied the cultural characteristics in ten isolates of Fusarium oxysporum f. sp. ciceri and showed circular, raised, cottony colony with entire margins. On the basis of colour of mycelium, white colour, creamy white colour and light purple colour was observed.

\section{Morphological variability}

Results (Table 2 and Plate II) revealed that all the eight representative isolate of Fusarium oxysporum f. sp. ciceri exhibited a wide range of variability in respect of size of microconidia, macro-conidia and chlamydospores. Average size of micro-conidia of the test isolates was ranged from $12.70 \times 3.5 \mu \mathrm{m}$ (FOC-8) to $17.20 \times 3.5 \mu \mathrm{m}$ (FOC-2). However, maximum micro-conidial size $(17.20 \times 3.5 \mu \mathrm{m})$ was recorded in isolate of Jalna (FOC-2). The second and third maximum micro-conidial size of $16.25 \times 3.5$ $\mu \mathrm{m}$ and $14.90 \times 3.5 \mu \mathrm{m}$ were recorded in the isolates of Beed (FOC-3) and Latur (FOC-5), respectively. This was followed by the isolates viz., Aurangabad (FOC-1), Nanded (FOC-6), Osmanabad (FOC-4) and Parbhani (FOC-7), produced medium sized microconidia, $14.50 \times 3.5 \mu \mathrm{m}, 14.50 \times 3.5 \mu \mathrm{m}$, $13.10 \times 3.5 \mu \mathrm{m}$ and $12.80 \times 3.5 \mu \mathrm{m}$, respectively. The isolate Hingoli (FOC-8) produced very small sized $(12.70 \times 3.5 \mu \mathrm{m})$ micro-conidia. The micro-conidia were more or less oval to cylindrical with no septation.

Average size of macro-conidia of the test isolates was ranged from $20.35 \times 7.00 \mu \mathrm{m}$ (FOC-6) to $30.50 \times 7.00 \mu \mathrm{m}$ (FOC-2). However, maximum macro-conidial size $(30.50 \times 7.00 \mu \mathrm{m})$ was recorded in isolate of Jalna (FOC-2). The second and third maximum macro-conidial size of $29.30 \times 7.00$ $\mu \mathrm{m}$ and $24.50 \times 7.00 \mu \mathrm{m}$ were recorded in the 
isolates of Beed (FOC-3) and Parbhani (FOC$7)$, respectively. This was followed by the isolates viz., Hingoli (FOC-8), Latur (FOC-5), Osmanabad (FOC-4) and Aurangabad (FOC1), produced medium sized macro-conidia, $24.40 \times 7.00 \mu \mathrm{m}, 23.80 \times 7.00 \mu \mathrm{m}, 23.20 \times$ $7.00 \mu \mathrm{m}$ and $21.00 \times 7.00 \mu \mathrm{m}$, respectively. The isolate Nanded (FOC-6) produced very small sized $(20.35 \times 7.00 \mu \mathrm{m})$ macro-conidia. The macro-conidia were typically sickle shaped curved, fusoid varied in the size and number of septation (3-5).

Average size of chlamydospores of the test isolates was ranged from $21.80 \times 19.60 \mu \mathrm{m}$ (FOC-2) to $16.50 \times 13.00 \mu \mathrm{m}$ (FOC-5). However, maximum chlamydospore size $(21.80 \times 19.60 \mu \mathrm{m})$ was recorded in isolate of Jalna (FOC-2). The second and third maximum chlamydospores size of $21.00 \mathrm{x}$ $18.30 \mu \mathrm{m}$ and $19.50 \times 18.65 \mu \mathrm{m}$ were recorded in the isolates of Beed (FOC-3) and Osmanabad (FOC-4), respectively. This was followed by the isolates viz., Nanded (FOC6), Aurangabad (FOC-1), Parbhani (FOC-7) and Hingoli (FOC-8) produced medium sized chlamydospores, $18.80 \times 16.80 \mu \mathrm{m}, 18.75 \times$ $16.80 \mu \mathrm{m}, 17.55 \mathrm{x} 16.20 \mu \mathrm{m}$ and $17.50 \mathrm{x}$ $16.20 \mu \mathrm{m}$, respectively. The isolate Latur (FOC-5), produced very small sized $(16.50 \mathrm{x}$ $13.00 \mu \mathrm{m}) \quad$ chlamydospore. The chlamydospores were round to oval in shape.

These results are in agreement with those reported by Prasad and Padwick, 1939; Ahmed, 2010; Patil, 2010; Korde, 2011 and Awachar, 2014, who also reported the size of macro-conidia, micro-conidia and chlamydospore, as in the range obtained in present investigation. Srivastava et al., (2004) reported maximum range of size of macroconidia from 19.98-46.62 x 3.33-6.66 $\mu \mathrm{m}$ to minimum $16.65-36.63 \times 3.33-4.99 \mu \mathrm{m}$ with 26 septa and also recorded the size of micro conidia with maximum 4.99-9.99 x 2.49-4.99 $\mu \mathrm{m}$ to minimum 4.66-4.99 $\mathrm{x} 1.66-4.99 \mu \mathrm{m}$.
Kadam, (2012) revealed that, macro-conidia were typically sickle shaped, curved, fusoid, varied in the size from $17.5 \mu \mathrm{m}$ to $49 \mu \mathrm{m}$ and septation was between 2 to 5 ; while, microconidia were reported in FOC-5 (Amravati) with size $(23.22 \mu \mathrm{m} \times 6.18 \mu \mathrm{m})$. Round chlamydospores were found in FOC-11 (Sangali), FOC-14 (Washim) and FOC-15 (Yawatmal); while, other FOC isolates were oval to spherical.

\section{Molecular characterization}

The eleven primers viz., OPA-1 to OPA-11 derived from Operon kit was screened for eight isolates of Fusarium oxysporum f. sp. ciceri from eight districts of Marathwada regions of Maharashtra. Among these, 10 primers gave highly reproducible and scorable amplifications and thus, they were exploited as most informative markers for molecular characterization study. The RAPD-PCR fingerprint pattern revealed that ten RAPD primers were generated a total 144 amplicons. Among 144 amplicons, 140 amplicons were found polymorphic and 4 amplicons were monomorphic. The Primer OPA-11 could produce highest number of bands (20) followed by OPA-10 and OPA-9 having 19 and 18 bands, respectively. However, the primer OPA-3 and OPA-4 showed lowest number of each bands 11 (Table 3 ).

The primers used in this study have shown polymorphism in the range of 91.66 per cent to 100 per cent. The primers OPA-1, OPA-3, OPA-4, OPA-5, OPA-8 and OPA-9 were showed maximum percent polymorphism $(100 \%)$. Rest of primers were showed per cent polymorphism in the range from 92.30 to 95.00 per cent. The primer OPA-2 was showed minimum percent polymorphism $(91.66 \%)$. A wide degree of variability was observed in RAPD pattern among eight isolates. The DNA fingerprint pattern generated by RAPD primer OPA-11 showed 
highly polymorphic pattern of fingerprinting. (Plate III). Primer OPA-11 has produced total number of 20 bands. Off them, 19 bands were found polymorphic and 1 was found monomorphic with showing percent polymorphism was 95.00 per cent. Similarly, OPA-2, OPA-7 and OPA-10 have produced total numbers of bands 12, 13 and 19; off them, 11, 12 and 18 bands were found polymorphism and one band each were monomorphic with showing 91.66, 92.30 and 94.73 per cent polymorphism, respectively (Plate III, IV and V).

The data generated by eleven RAPD primers were used to establish the genetic relationship among eight isolates of Fusarium oxysporum f. sp. ciceri by using the Jaccard's similarity coefficient (Jaccard's, 1908). Statistical analyses were performed using NTSYS-pc version 2.21c (Exeter Software, NY, USA). Dendrogram was generated by vising the SAHN (Sequential Agglomerative Hierarchical Nested) programme of NTSYS and matrix comparison was done using $\mathrm{COPH}$ and MXCOMP programmes and correlated with the original distance matrices in order to test for the association between the cluster in the dendrogram and the Dice matrix. The unweighted pair group method with arithmetic mean (UPGMA) cluster analysis method was followed for construction of phylogenetic tree. The dendrogram analysis using RAPD similarity matrix categorized all 8 isolates into two major clusters, containing four groups (Plate VI).

Cluster I and cluster II comprised eight isolates together showed 48 per cent similarity. The cluster I comprised two isolates together showing maximum similarity in the range of 57.60 per cent. The isolates FOC-1 (Aurangabad) and FOC-6 (Nanded) of cluster I was found more similar to each other showing 57.60 per cent; however, cluster II comprised six isolates (FOC-2, FOC-3, FOC-
4, FOC-5, FOC-7 and FOC-8) together showing 53.88 per cent similarity. The members of isolates FOC-2 and FOC-3 of cluster II was shown maximum of 68 per cent similarity to each other; while, isolates FOC-4 and FOC-5 have shown 59.00 per cent similarity to each other. The members of isolates FOC-7 and FOC-8 of cluster II was shown maximum of 100 per cent similarity. All of these six isolates of cluster II were from different region showing maximum similarity in the range of 59.00 to 100 per cent.

Many molecular studies have been performed to identify genetic polymorphism between races of Fusarium oxysporum f. sp. ciceri and to differentiate other wilt and root rot pathogen (Barve et al., 2001; Jimenez-Gasco et al., 2003; Mandhare et al., 2011; Katkar, 2013 and Mahsane, 2013). Fusarium oxysporum f. sp. ciceri is monophyletic (Jimenez-Gasco et al., 2002) however, it exhibit considerable variation in symptoms types and pathogenicity on chickpea according to geographical location. Bayraktar et al., (2009) detected a high degree of genetic variability among Fusarium oxysporum f. sp. ciceri isolates and separated them into three distinct groups.

Kadam and Mane (2012) studied genetic similarity between 0.08 FOC-14 (Washim) and FOC-3 (Parbhani), 0.38 FOC-1 (Dhule) and FOC-14 (Washim). UPGMA cluster A, isolates FOC-7 (Satara) and FOC-13 (Pune) as type race-4, FOC-6 and FOC-1 as type race- 1 and cluster $\mathrm{B}, \mathrm{FOC}-3$ (Parbhani) and FOC-14 (Washim) as type race-6. Katkar and Mane (2012) assessed the genetic variability within four races (5 isolates) of Fusarium oxysporum f. sp. ciceri were screened by using 30 RAPD primers, Off 155 bands, 149 bands were polymorphic and level of polymorphism was 96.12 per cent. 
Table.1 Cultural variability of Fusarium oxysporum f. sp. ciceri isolates from Marathwada region on PDA medium

\begin{tabular}{|l|c|c|l|c|c|}
\hline \multicolumn{1}{|c|}{$\begin{array}{c}\text { Name of } \\
\text { Isolates }\end{array}$} & $\begin{array}{c}\text { Isolate } \\
\text { code }\end{array}$ & $\begin{array}{c}\text { Colony } \\
\text { diameter }(\mathbf{m m})\end{array}$ & \multicolumn{1}{|c|}{ Colony characters } & $\begin{array}{l}\text { Pigmentation } \\
\text { colour }\end{array}$ & Sporulation \\
\hline Aurangabad & FOC-1 & 87.66 & $\begin{array}{l}\text { Submerged, white sparse } \\
\text { growth in concentric ring, }\end{array}$ & Pale white & +++ \\
\hline Jalna & FOC-2 & 90.00 & $\begin{array}{l}\text { Partially submerged, white } \\
\text { spars dense growth with } \\
\text { smooth margin }\end{array}$ & Bright white & ++++ \\
\hline Beed & FOC-3 & 88.66 & $\begin{array}{l}\text { Submerged, white sparse } \\
\text { growth with smooth margin }\end{array}$ & Bright white & +++ \\
\hline Osmanabad & FOC-4 & 88.33 & $\begin{array}{l}\text { White cottony and fluffy } \\
\text { growth with smooth margin }\end{array}$ & Creamy white & ++++ \\
\hline Latur & FOC-5 & 88.66 & $\begin{array}{l}\text { White cottony and fluffy } \\
\text { growth with smooth margin }\end{array}$ & Creamy white & ++ \\
\hline Nanded & FOC-6 & 88.00 & $\begin{array}{l}\text { Submerged, white sparse } \\
\text { growth in concentric ring, } \\
\text { thread like flagging, Pale white }\end{array}$ & ++++ \\
\hline Parbhani & FOC-7 & 89.66 & $\begin{array}{l}\text { Compact and fluffy growth of } \\
\text { white mycelium Purple Pink }\end{array}$ & + +++ \\
\hline Hingoli & FOC-8 & 88.33 & $\begin{array}{l}\text { Thick, compact and fluffy } \\
\text { growth of bright white } \\
\text { mycelium Bright white }\end{array}$ & ++ \\
\hline
\end{tabular}

- $=$ No $\quad+=$ Poor $\quad++=$ Fair $\quad+++=$ Good $\quad++++=$ Excellent
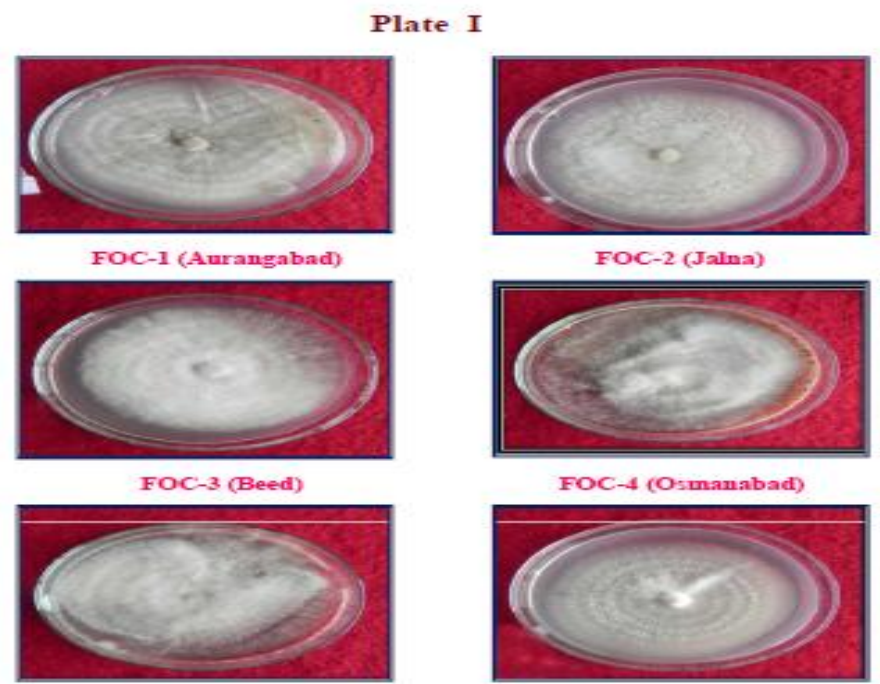

FOC-4 (Osmanabad)

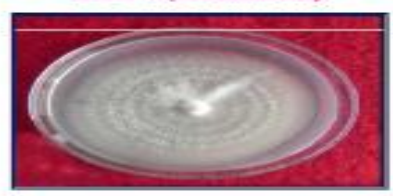

FOC-5 (Latur)

FOC-6 (Nanded)
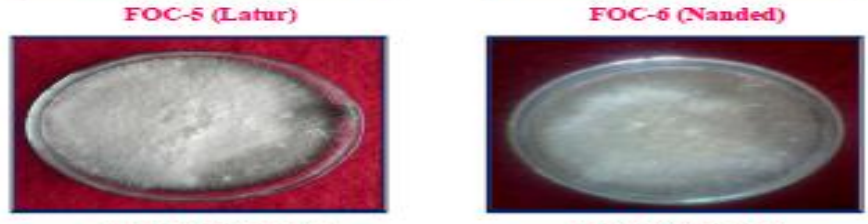

FOC-7 (Parbhani)

FOC-S (Hingoli)

Cultural variability of Fusarium oxysportum f. sp. ciceri isolates

from Marathwada region 
Table.2 Morphological variability of Fusarium oxysporum f. sp. ciceri isolates from Marathwada region

\begin{tabular}{|c|c|c|c|c|c|c|c|c|c|c|c|c|c|}
\hline \multirow{3}{*}{$\begin{array}{l}\text { Name of } \\
\text { isolate }\end{array}$} & \multirow{3}{*}{$\begin{array}{l}\text { Isolate } \\
\text { code }\end{array}$} & \multicolumn{5}{|c|}{ Micro-conidia } & \multicolumn{5}{|c|}{ Macro-conidia } & \multicolumn{2}{|c|}{ Chlamydospores } \\
\hline & & \multicolumn{2}{|c|}{ Length $(\mu \mathrm{m})$} & \multicolumn{2}{|c|}{ Breath $(\mu \mathrm{m})$} & \multirow{2}{*}{ Septa } & \multicolumn{2}{|c|}{ Length $(\boldsymbol{\mu m})$} & \multicolumn{2}{|c|}{ Breath $(\mu \mathrm{m})$} & \multirow{2}{*}{ Septa } & \multirow{2}{*}{$\begin{array}{c}\begin{array}{c}\text { Length } \\
(\mu \mathrm{m})\end{array} \\
\end{array}$} & \multirow{2}{*}{$\begin{array}{r}\text { Breath } \\
(\mu \mathrm{m})\end{array}$} \\
\hline & & Average & Range & Average & Range & & Average & Range & Average & Range & & & \\
\hline Aurangabad & FOC-1 & 14.50 & $10.5-20$ & 3.50 & $0-3.5$ & 00 & 21.00 & $17-35$ & 7.00 & $0-7.0$ & $3-5$ & 18.75 & 16.80 \\
\hline Jalna & FOC-2 & 17.20 & $10.5-20$ & 3.50 & $0-3.5$ & 00 & 30.50 & $21-40$ & 7.00 & $0-7.0$ & $3-5$ & 21.80 & 19.60 \\
\hline Beed & FOC-3 & 16.25 & $15-21$ & 3.50 & $0-3.5$ & 00 & 29.30 & $20-35$ & 7.00 & $0-7.0$ & $3-5$ & 21.00 & 18.30 \\
\hline Osmanabad & FOC-4 & 13.10 & $10-15$ & 3.50 & $0-3.5$ & 00 & 23.20 & $20-35$ & 7.00 & $0-7.0$ & $3-5$ & 18.65 & 19.50 \\
\hline Latur & FOC-5 & 14.90 & $7-17.5$ & 3.50 & $0-3.5$ & 00 & 23.80 & $17-28$ & 7.00 & $0-7.0$ & $3-5$ & 16.50 & 13.00 \\
\hline Nanded & FOC-6 & 14.50 & $7-17.5$ & 3.50 & $0-3.5$ & 00 & 20.35 & $17-28$ & 7.00 & $0-7.0$ & $3-5$ & 18.80 & 16.80 \\
\hline Parbhani & FOC-7 & 12.80 & $7-14$ & 3.50 & $0-3.5$ & 00 & 24.50 & $17-35$ & 7.00 & $0-7.0$ & $3-5$ & 17.55 & 16.20 \\
\hline Hingoli & FOC-8 & 12.70 & $7-14$ & 3.50 & $0-3.5$ & 00 & 24.40 & $17-35$ & 7.00 & $0-7.0$ & $3-5$ & 17.50 & 16.20 \\
\hline
\end{tabular}

Plate II

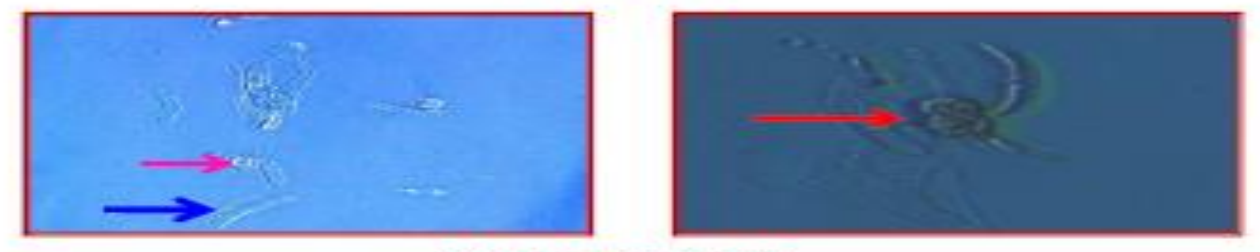

FOC-1 (Aurangabad)
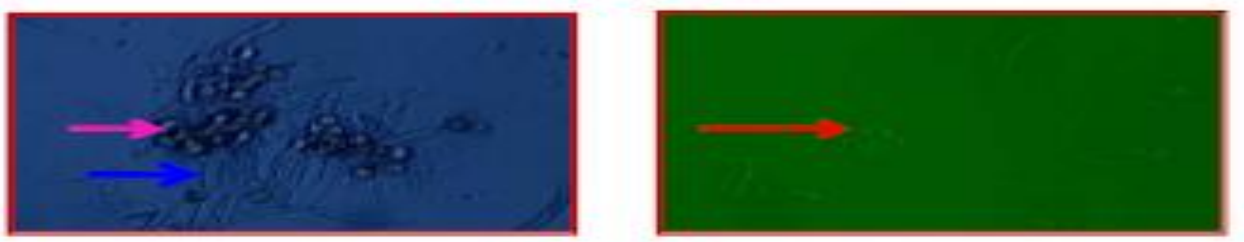

FOC-2 (Jalna)

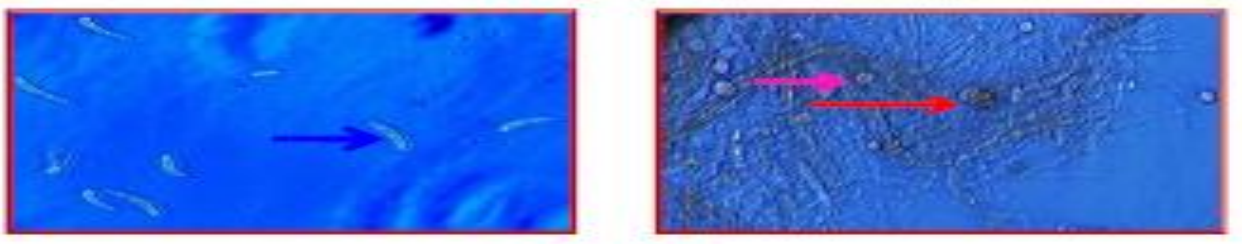

FOC-3 (Beed)

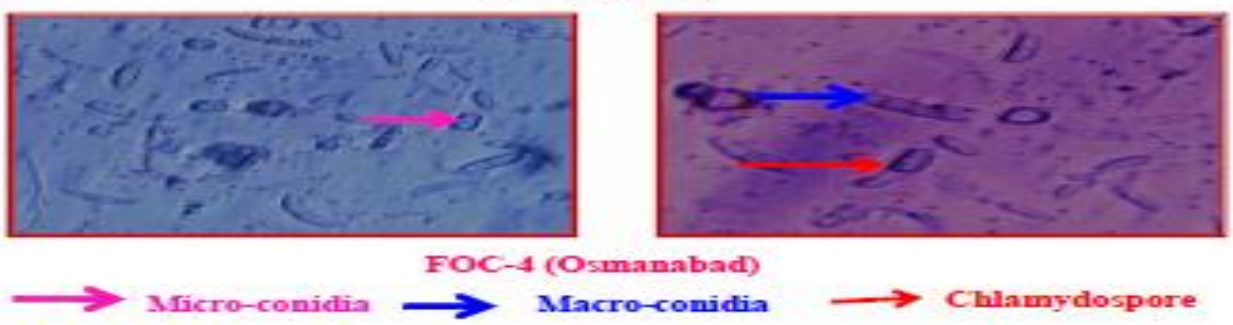

Morphological variability of Fusarium oxysporum f. sp. ciceri isolates from Marathwada region 

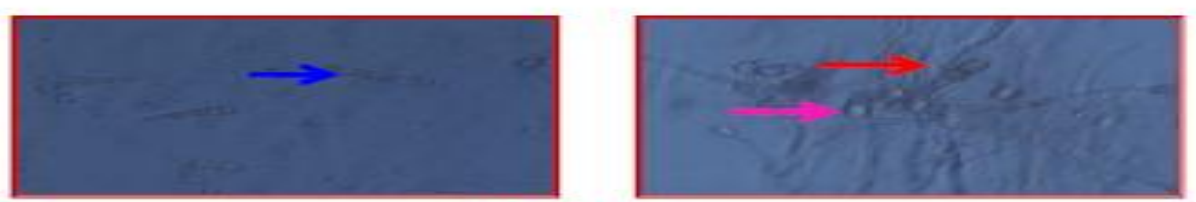

FOC-5 (Latur)

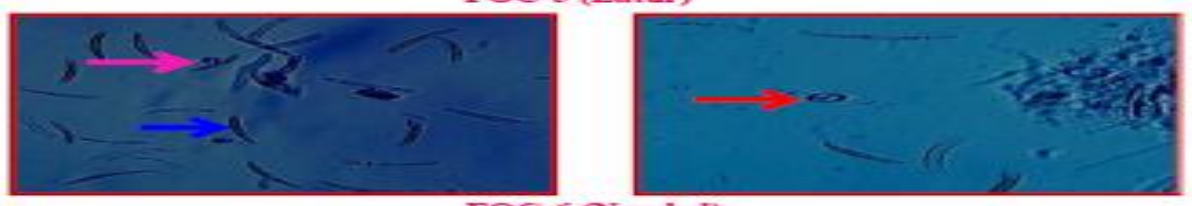

FOC-6 (Namiled)

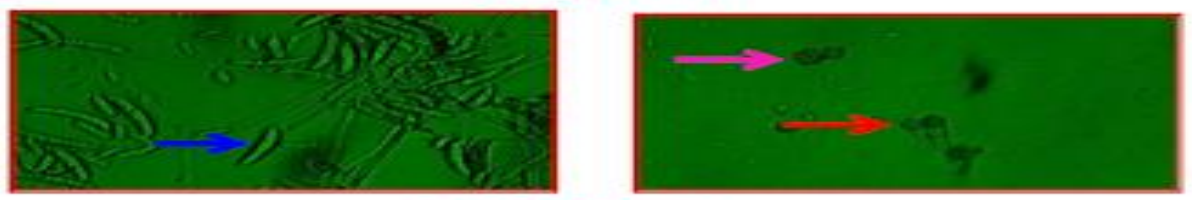

FOC-7 (Parbhani)
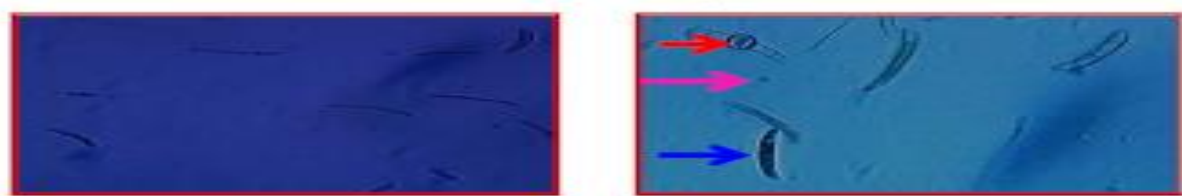

FOC-s (Hingoli)

Micro-conielia

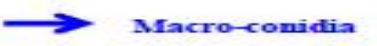

$\longrightarrow$ Chlamydospore

M forphological variability of Freserinu axysporzm f. sp-ciceri

isolates from Mrarathwada region

Table.3 Per cent polymorphism among isolates of Fusarium oxysporum f. sp. ciceri on the basis of RAPD analysis

\begin{tabular}{|c|c|c|c|c|c|c|}
\hline $\begin{array}{l}\text { Sr. } \\
\text { No. }\end{array}$ & $\begin{array}{c}\text { RAPD } \\
\text { primers }\end{array}$ & $\begin{array}{l}\text { Sequence of primers } \\
5\end{array}$ & $\begin{array}{l}\text { Total no. } \\
\text { of bands }\end{array}$ & $\begin{array}{l}\text { Monomorphi } \\
\text { c bands }\end{array}$ & $\begin{array}{l}\text { Polymorphic } \\
\text { bands }\end{array}$ & $\begin{array}{c}\text { Polymorphism } \\
(\%)\end{array}$ \\
\hline 1 & OPA-1 & 5' CAGGCCCTTC3 & 13 & - & 13 & 100 \\
\hline 2 & OPA-02 & 5' TGCCGAGCTG3 & 12 & 1 & 11 & 91.66 \\
\hline 3 & OPA-03 & 5' AGTCAGCCAC3 & 11 & - & 11 & 100 \\
\hline 4 & OPA-04 & 5' AATCGGGCTG3 & 11 & - & 11 & 100 \\
\hline 5 & OPA-05 & 5' AGGGGTCTTG3 & 15 & - & 15 & 100 \\
\hline 6 & OPA-07 & 5' GAAACGGGTG3 & 13 & 1 & 12 & 92.30 \\
\hline 7 & OPA-08 & 5' GTGACGTAGG3 & 12 & - & 12 & 100 \\
\hline 8 & OPA-09 & 5' GGGTAACGCC3 & 18 & - & 18 & 100 \\
\hline 9 & OPA-10 & 5' GTG ATCGC AG3 & 19 & 1 & 18 & 94.73 \\
\hline 10 & OPA-11 & 5' CAATCGCCGT3 & 20 & 1 & 19 & 95.00 \\
\hline \multicolumn{3}{|c|}{ Total } & 144 & 04 & 140 & 97.36 \\
\hline
\end{tabular}


Int.J.Curr.Microbiol.App.Sci (2017) 6(4): 2721-2734

Plate III
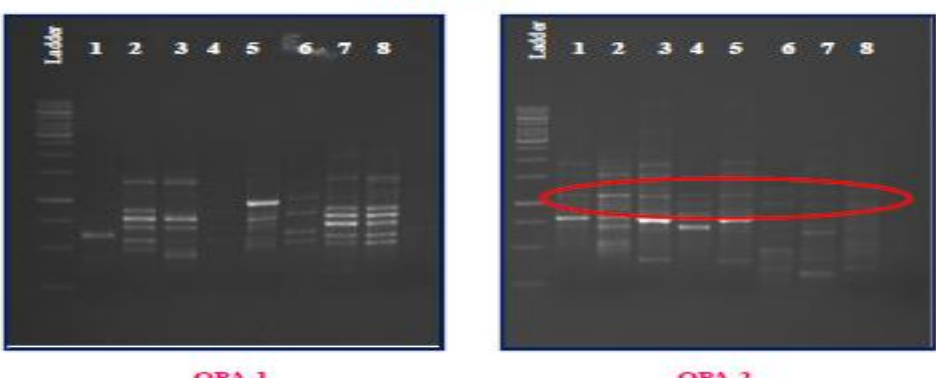

OPA-1

OPA-2

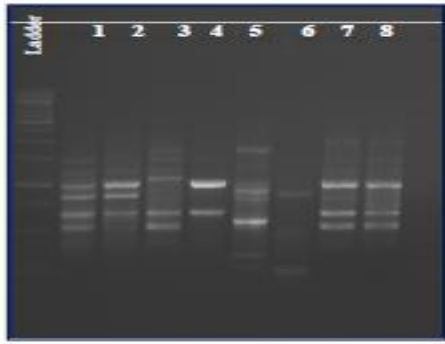

OPA-3

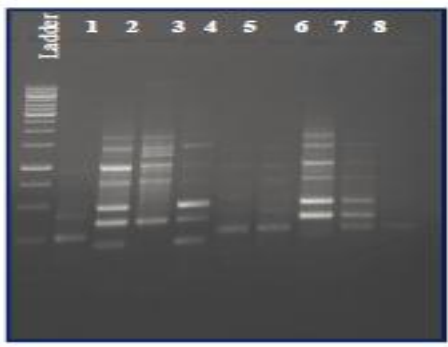

OPA-4

RAPD fingerprint profile of isolates of Fusarinum oxysporzum $f$ sp. ciceri generated

by primers OPA-1, OPA-2, OPA-3 and OPA-4 = MI; 1 l-b ladder; lane 1-8, Fusarinum oxysporsum f. sp. ciceri isolates 1-s, respectively.

Plate IV

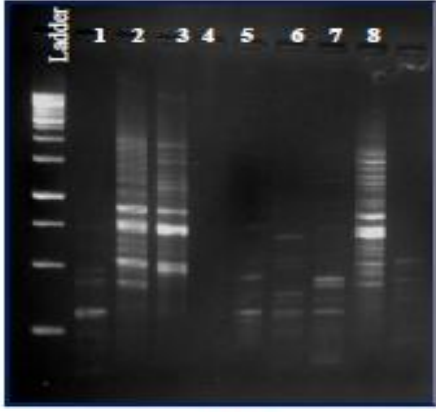

OPA-5

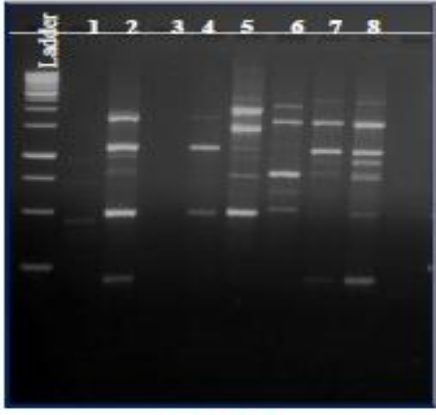

OPA-S

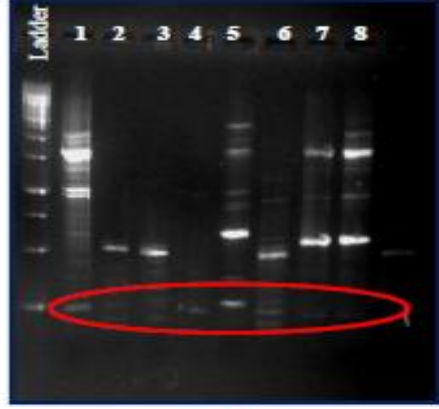

OPA-7

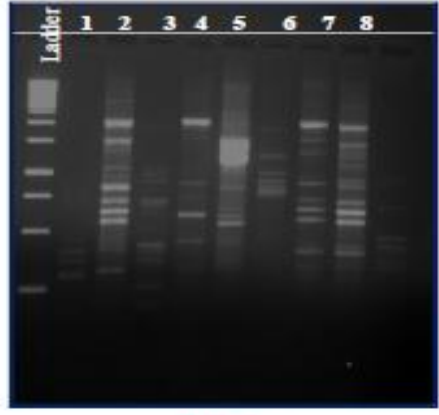

OPA-9

RAPD fingerprint profile of isolates of Fusarium oxyspornum $f$ sp. ciceri generated by primers OPA-5, OPA-7, OPA-8 and OPA-9 : M; 1 kb ladder; lane 1-8, Fusarium axysponum $\mathrm{f}$. sp. ciceri isolates $1-8$, respectively. 


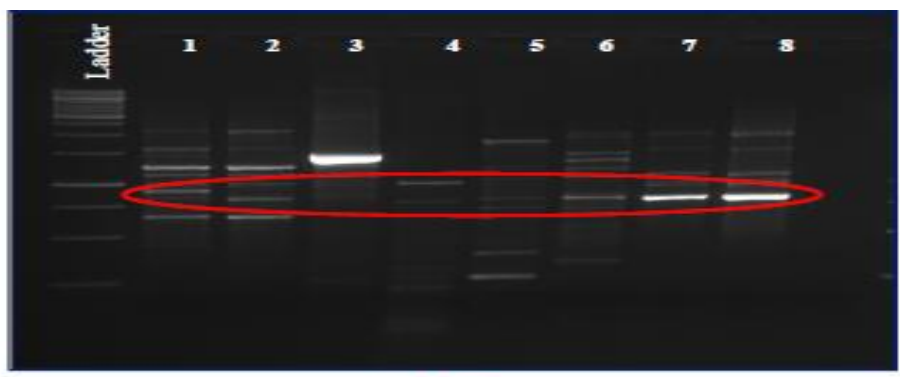

OPA-10

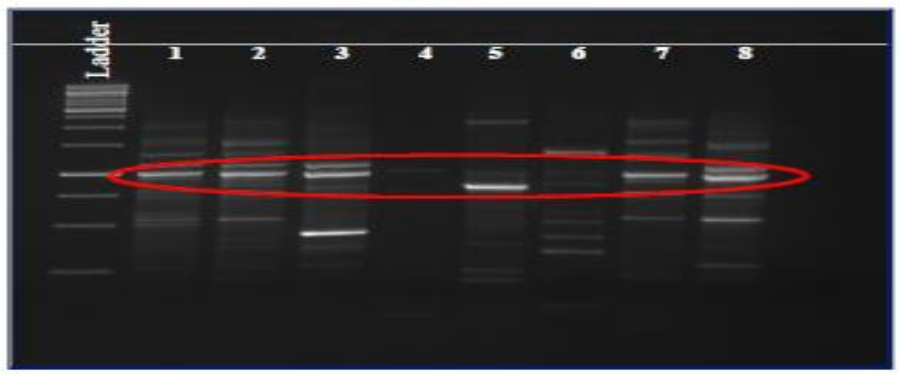

OPA-11

RAPD fingerprint profile of isolates of Fusarium oxyspornm f. sp. ciceri generated by primer OPA-10 and OPA-11 : M; 1 k:b ladder; lane $1-8$, Fusarisem oxysporzm f. sp. ciceri isolates $1-8$, respectively.

Plate VI

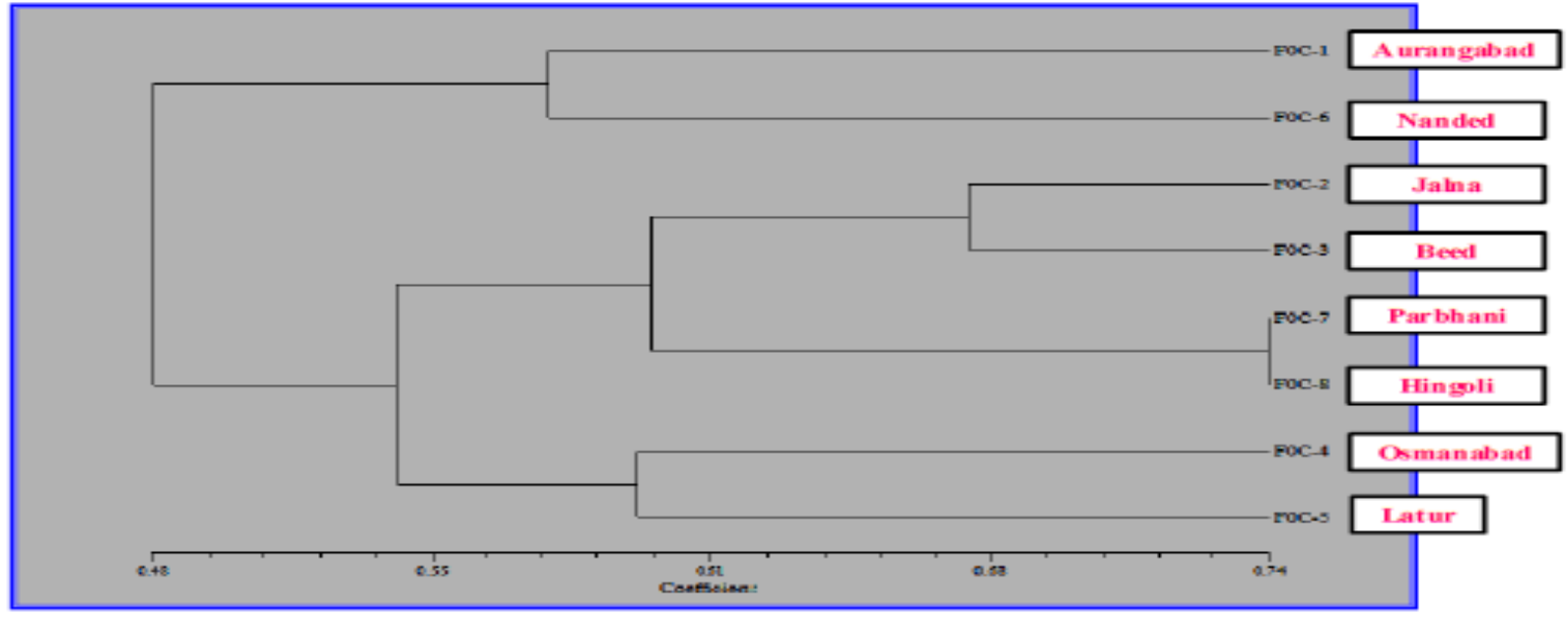

Dendrogram generated using UPGMA analysis dem onstrating the genetic relationship among eight kolates of Fusark̈m axysporum $\mathrm{f}$ sp. cíceri based on RAPD data

The RAPD primers OPA-13, OPA-16, OPA18, OPB-14 and OPB-15 showed monomorphic banding pattern. Atram et al. (2015) also studied the genetic diversity among the 7 isolates of Fusarium oxysporum f. sp. ciceri by using RAPD primers of OPF series. Out of 108 bands, 101 bands were polymorphic and level of polymorphism was
93.18 per cent. The Wardha isolates (FOC-4) was found to have higher value of similarity coefficient (0.74); whereas, Rahuri isolates (FOC-2) was found to have lower value of similarity coefficient $(0.49)$.

Disease management programme, genetic diversity plays an important role. Knowledge of the nature of variation and distribution of 
pathogen races is required for the efficient disease management through the use of resistant cultivars. In fact it is an essential prerequisite while initiating a breeding programme, because the choice of potential and diverse parents determines the success of such programme. The selection of diverse parents in breeding programme serve the purpose of combining desirable genes, so as to obtain superior recombination's and to get resistant cultivars which can be exploited commercially in shortest possible period. Genetic diversity and variation studies initially conducted using qualitative and quantitative straits were mostly based on using various statistical methods such as analysis of variance, diversity analysis and principal components analysis. Also the morphological study, pathogenicity test are cumbersome, time consuming, require extensive facilities and are influenced by variability inherent in the experimental system. Furthermore, pathogenic data alone provide no information about genetic diversity within or relatedness among races of the pathogen. However, recently molecular markers are being widely used in various areas as an important tool for evaluating genetic diversity and determining the identity of isolates. The results provide information useful to future population for developing region specific resistant varieties. Based on genetic diversity analysis, it clearly indicated that the existence of highly variable populations of Fusarium oxysporum f. sp. ciceri, this pathogen without any linkage of geographical origin.

\section{References}

Ahmad, M. A. (2010). Variability in Fusarium oxysporum f. sp. ciceri for chickpea wilt resistance in Pakistan. $\mathrm{Ph}$. D. (Agri.) thesis, (Abs.) submitted to Quaid-i-Azam University, Islamabad, Pakistan.

Anonymous, (2014). Directorate of
Economics and Statistics, Department of Agriculture and Cooperation. Agricultural statistics at a glance. pp: 94-96.

Anser, M. and Srivastava M. (2013). Morphological variability and pathogenic reactions of Fusarium oxysporum f. sp. ciceri isolates to cultivars of chickpea. Ann. Pl. Protec. Sci. 21 (2): 345-348.

Atram, P. Katker, M., Shyamsunder and Mane, S. S. (2015). Genetic diversity amongst the isolates of Fusarium oxysporum $f$. sp. ciceri causing chickpea wilt from agro climatic regions of Maharashtra though RAPD markers. Paper presented in National symposium on plant disease management for food security on 9-11 November, held at Akola. pp: 37.

Awachar, M. K. (2014). Studies on morphological variability of Fusarium oxysporum f. sp. ciceri causing wilt of chickpea. M. Sc. (Agri.) thesis submitted to MPKV, Rahuri (India).

Barve, M. P., Haware, M. P., Sainani, M. N., Ranjekar, P. K. and Gupta, V. S. (2001). Potential of microsatellites to distinguish four races of Fusarium oxysporum f. sp. ciceri prevalent in India. Theor. Appl. Genet. 102: 138147.

Bayraktar, H., Dolar, F. S. and Maden, S. (2007). Use of RAPD and ISSR marker in detection of genetic variation and population structure among Fusarium oxysporum f. sp. ciceris isolates on chickpea in Turkey. J. Phytopathol. 156 (3): 146-54.

Butler, E. J. (1918). Fungi and diseases of plants. Book published. (M. C. Saxena, K. B. Singh, edi.), CABI Publishing, CAB Int., Wallingford, UK. 233-270.

Dhar, V. and Gurha, S. N. (1998). Integrated management of chickpea diseases. (Rajeev, K., Upadhyay, K. G., Mukerji, 
B. P., Chamola and Dubey, O. P. (edi.)), APH Pub. Co., New Delhi. (India). pp: 249.

Iruela, M., Rubio, J., Cubero, J. I., Gil, J. and Millan, T. (2002). Phylogenetic analysis in the genus Cicer and cultivated chickpea using RAPD and ISSR markers, Theor. Appl. Genet. 104: 643651.

Islam, R., Momotaz, R., Islam, M. and Ahmed A. U. (2011). Annual Report on variability studies of Fusarium oxysporum f. sp. ciceri causing chickpea wilt. Bangladesh Research Institute, Bangladesh.

Jalali, B. L. and Chand, H. (1992). Diseases of Cereals and Pulses. (U. S. Singh, A. N. Mukhopadhayay, J. Kumar, and H. S. Chaube, edi.) Prentice Hall, Englewood Cliffs, NY. 1-429-444.

Jimenez-Gasco, M. M., Milgroom, M. G. and Jimenez-Diaz, R. M. (2002). Gene genealogies support Fusarium oxysporum f. sp. ciceris as a monophyletic group. Plant Pathology. 51: $72-77$.

Jimenez-Gasco, M. M., Milgroom, M. G. and Jimenez-Diaz, R. M. (2003). Development of a specific polymerase chain reaction based assay for identification of Fusarium oxysporum $\mathrm{f}$. sp. ciceris and its pathogenic races 0 , 1A, 5 and 6. American Phytopathol. Soc. 93 (2): 200-209.

Kadam, N. (2012). Molecular characterization of different isolates of Fusarium oxysporum f. sp. ciceri causing chickpea wilt from Maharashtra. M. Sc. (Agri.) thesis submitted to Dr. PDKV, Akola (India).

Kadam, N. and Mane, S. S. (2012). Molecular characterization of different isolates of Fusarium oxysporum f. sp. ciceri causing chickpea wilt in Maharashtra using RAPD. J. Pl. Dis. Sci. 7 (2): 206209.
Katkar M. (2012). Molecular characterization races of Fusarium oxysporum f. sp ciceri through RAPD and ISSR markers. M. Sc. (Agri.) thesis submitted to Dr. PDKV, Akola (India).

Katkar, M. and Mane, S. S. (2012). Characterization of Indian races of Fusarium oxysporum f. sp. ciceri through RAPD markers. Int. J. Agric. Environ. Biotech. 5 (4): 323-328.

Kelly, A., Jimenez, A., Bainbridge, B. W., Heale, J. B., Perez-Artes, E. and Jimenez-Diaz, R. M. (1994). Use of genetic fingerprinting and random amplified polymorphic DNA to characterize pathogens of Fusarium oxysporum f. sp. ciceris infecting chickpea. Phytopathol. 4 (11): 12931298.

Khilare, V. C., Ahmed, R., Chavan, S. S. and Kohire, O. D. (2009). Management of Fusarium oxysporum f. sp. ciceri by different fungicides. Bioinfolet. 6 : 4143.

Korde, M. G. (2011). Studies on Fusarium wilt of chickpea caused by Fusarium oxysporum f. sp. ciceri (Padwik) Synder and Hansan. M. Sc. (Agri.) thesis submitted to VNMKV, Parbhani (India).

Mahsane, A. O. (2013). Studies on genetic diversity of Fusarium udum causing wilt of pigeon pea (Cajanus cajan (L.) Millsp). M. Sc. thesis submitted to V.N.M.K.V., Parbhani (M.S.). India.

Mandhare, V. K., Deshmukh, G. P., Patil, J. V., Kale, A. A. and Chavan, U. D. (2011). Morphological, pathogenic and molecular characterization of Fusarium oxysporum f. sp. ciceri isolates from Maharashtra, India. Indonesian $J$. Agricultural Sci., 12 (2): 47-56.

Nagare, A. J. (2011). Studies on safflower wilt caused by Fusarium oxysporum f. sp. carthami (Klisiewicz and Houston). M. Sc. (Agri.) thesis submitted to 
VNMKV, Parbhani (India).

Nema, K. G. and M. N. Khare. (1973). A conspectus of wilt of Bengal gram in Madhya pradesh. Symposium on wilt problem and breeding for wilt resistance in Bengal gram, Sept. 1973 at Indian Agril. Res. Institute, New Delhi, India. pp: $1-4$.

Nene, Y. L. and Reddy, M. V. (1987). Chickpea diseases and their control. Phytopath. 42: 499-505.

Patil, V. B. (2010). Studies on survey and management of chickpea wilt in Marathwada region. Ph. D. (Agri.) thesis submitted to VNMKV, Parbhani (India).

Prasad, N. and Padwick, G. W. (1939). The genus Fusarium 11. A species of Fusarium as a cause of wilt of gram (C. arietinum L.). Indian J. Agri. Sci. 9: 371-380.

Rajesh, P. N., Sant, V. J., Gupta, V. S.,
Muehlbauer, F. J and Rajenkar, P. K. (2002). Genetic relationships among annual and perennial wild species of Cicer using inter simple sequence repeat (ISSR) polymorphism. Euphytica. 29: 15-23.

Reddy, Y. S. (2002). Studies on wilt complex of chickpea (Cicer arientinum L.). M. Sc. (Agri.) thesis, I.G.N.U., Raipur (CG), India.

Srivastava, A., Singh, S. N. and Agrawal, S. C. (2004). Studies on prevalence and identification of new races of Fusarium oxysporum f. sp. ciceri, incitant of chickpea wilt from Madhya Pradesh. India. J. Pl. Pathol. 22 (1 \& 2): 88-90.

Williams, J. G. K., Kubelik, A. R., Livak, K. J., Rafalsky, J. A. and Tingey, S. V. (1990). DNA polymorphism amplified by arbitary primers are useful as genetic markers. Nuceic. Acid. Res. 18: 6531.

\section{How to cite this article:}

Thaware, D.S., O.D. Kohire and Gholve, V.M. 2017. Cultural, Morphological and Molecular Variability of Fusarium oxysporum f. sp. Ciceri Isolates by RAPD Method. Int.J.Curr.Microbiol.App.Sci. 6(4): 2721-2734. doi: http://dx.doi.org/10.20546/ijcmas.2017.604.316 